\title{
The Effect of Service Tax Officials, Penalties for Late Payments and Reporting on The Taxpayer Compliance Non-Star Hotels
}

\author{
Ely Kartikaningdyaha, ${ }^{\mathbf{a}, *}$, R. Qinanti Nuzurawan ${ }^{\mathbf{b}}$ \\ a Jurusan Manajemen Bisnis, Politeknik Negeri Batam, ely@polibatam.ac.id \\ bJurusan Manajemen Bisnis, Politeknik Negeri Batam, raja.qinanti@gmail.com
}

\begin{abstract}
This research conducted to determine the effect of service tax officials, penalties for late payments and reporting on the taxpayer compliance non-star hotels. Mechanical determination of sample using purposive sampling technique with a total sample of 116 taxpayer. The type of data used are primary data. Methods of data collection is done by questionnaire. These results indicate that the service tax officials, penalties for late payments and reporting have a positive and significant effect on the taxpayer compliance non-star hotels. The limitations in the study is the lack of understanding of respondents to the statements in the questionnaire and carrying attitude and seriousness in answering statement. In the study also suggested that government provide socialization with both the taxpayer so they better understand the tax penalties and causes sanctions fines on taxpayers.
\end{abstract}

Keywords: service tax officials, tax penalties and taxpayer compliance

*Corresponding author. E-mail: ely@ polibatam.ac.id 


\section{Introduction}

Taxes serves as a source of funds used to finance government expenditures (Waluyo, 2011). Tax collection in Indonesia was based on the Constitution of 1945 Section 23A which provides that taxes and other fees for the purposes of coercive state governed by the Act. Moreover, taxation is a form of devotion obligation of Citizens in the State and National Development Financing, the reciprocal can be felt directly by the taxpayer.

Based on what has been mentioned, that the coercive tax collection for the purposes of the State, that is the way the tax collection itself coercive. Forcing within the meaning of the Taxpayer is required to pay taxes on time, because paying taxes will affect the development of the State. If the tax payment is no element of coercion, it happens rather than facilitate the development of the State, but will hamper development because of lack of development funds.

Responsibility for paying taxes as citizens, an obligation that must be carried out by each individual. This is consistent with the concept of self-assessment that is now run in calculating and reporting tax. Selfassessment is a tax system that provides trust and responsibilities to taxpayers in order to take the initiative to register themselves to get a Taxpayer Identification Number (TIN) compute, calculate, and report on their own pay taxes owed.

Taxpayer awareness is very closely related and directly proportional to the compliance of paying taxes. If the level of consciousness is low, lower the compliance and if a high level of consciousness, the higher the compliance. Therefore, it is the duty of each element of the general public and local government in particular to build public awareness in order to create Obedient Taxpayer Tax.

The willingness to pay taxes can be affected by several factors, including the condition of the tax administration system of a country, service to taxpayers, enforcement of tax laws and tax rates (Devano and Rahayu, 2006). The role of the taxpayer in the tax collection system is crucial to achieve the target of tax revenue, to be able to further optimize the local tax revenue, one of which Taxes Non-Star Hotel is by increasing the Taxpayer Compliance itself. According Devano and Rahayu (2006), tax compliance is influenced by several factors, including the condition of consciousness taxation system of a country, service to the taxpayer, tax law, tax audits, and tax rates, which is a formal or governmental factor.

The level of tax compliance is also influenced by the quality of service. The better the quality of service will lead to higher levels of tax compliance. Tax penalty is an act done as a result of violations of tax laws that do taxpayer and the authorities resulting in state losses (Resmi, 2015). As a result of the violations committed then they will be penalized awareness of taxation and criminal sanctions set out in the Tax Law.

Broadly speaking, awareness of taxation within the meaning of the procedure includes the steps include data collection taxpayer, taxpayer registration, tax assessment, tax audit and tax collection. The stages are not solid is a source of fraud. Awareness of taxation is thought to have relevance on tax compliance. In connection with the required data collection and registration of taxpayers, tax assessment, inspection and tax collection are good, it will have an impact on tax compliance hotels in paying taxes.

Suciningsih, Bagia \& Cipta (2014) states that the tax penalties positive and significant impact on tax compliance in paying property taxes and awareness taxpayer positive and significant impact on tax compliance and research Saputra (2015) the quality of tax services have a significant effect positive on tax compliance, while Dewi and Sukartha (2015) concluded that the tax penalties and service quality positive influence on tax compliance in paying taxes hotel.

This study aims to examine the Influence between payment and reporting on the level of tax compliance of non-star hotel. So that researchers formulate a problem of how the influence of service to the level of tax compliance, how the influence of penalties for late payment and reporting of taxes on tax compliance Non-star hotel in Batam. The study is meant to contribute in providing evidence that the service, penalties for late payment and reporting affect the level of tax compliance of non-star hotel.

\section{Literature Review}

According Constitution number 28 Year 2007 on General Provisions and Tax Procedures states that the tax is a mandatory contribution to the state owed by private persons or entities that are enforceable under the Act, by not getting the rewards directly and used for the purposes of State for prosperity.

According to Resmi (2015) Tax as an obligation to give up some of the wealth to the state treasury caused a situation, events, and actions that give a certain 
position, but not as punishment, according to the regulations set by the government and can be enforced, but there is no merit reciprocal from direct state, to maintain the general welfare.

In accordance with Regulation of City of Batam No. 5 of 2011 concerning Regional Tax Batam, Local Taxes, hereinafter called the tax is obligatory contribution to a region that is owed by private persons or entities that are enforceable under the Act, by not getting the rewards directly and used for the purposes of Regions for the greatest prosperity of the people.

Regional Regulation of Batam No. 5 of 2011 concerning Regional Tax Batam, there are several types of taxes, namely (1) Taxes (2) Tax Restaurants (3) Tax Entertainment (4) Advertisement Tax (5) street lighting tax (6) Tax Non-Metallic minerals (7) parking tax with a tax period of 1 (one) month.

The Batam City Regional Regulation No. 5 of 2011 concerning Regional Tax Batam, Hotel Tax is a tax on services provided by the hotel. The object of hotel tax is a service provided by the Hotel to payment, including supporting services such as telephone service, facsimile, internet, xerox, laundry, transportation, and other similar facilities of other services provided or managed the hotel as the completeness of the hotel to give comfort and comfort, including sports and entertainment facilities.

Taxable Hotel is a private person or agency that made the payment to persons or entities that seek private or hotel. Basic Hotel Tax is the amount of payment or that must be paid to the hotel with Tax Rates Hotel that has been stipulated in Local Regulation of Batam number 5 of 2011 amounted to $10 \%$ (ten percent) is calculated by multiplying the tax rate and the tax base.

Service was how to minister to help administer or prepare everything necessary purposes. Services tax authorities can be interpreted as how the tax officer to help administer or prepare all purposes needed by the taxpayer (Jatmiko, 2006). The tax authority is in charge to serve the taxpayer (WP) in paying taxes. Systematics tax officials in performing their duties is to assist payers in evading taxes payable in Batam Revenue Service, to tell how the steps in paying taxes.

Tax sanction is an act done as a result of violations of tax laws that do taxpayer and the authorities resulting in state losses (Resmi, 2015). As a result of offenses committed will be penalized awareness of taxation and criminal sanctions set out in the Tax Law. Sanctions given because of the late payment of taxes and tax reporting delays.

According Devano (2006) stated that the imposition of tax penalties applied as a result of non-fulfillment of tax obligations by the taxpayer as mandated by the tax laws. Imposition of sanctions to taxpayers could increase taxpayer compliance itself. If the imposition of taxation is still not enough awareness of the sanctions that are heavier will be applied. Administrative sanctions in the form of interest of $2 \%$ (two percent) a month is calculated from the tax less or overdue for a maximum period of 24 (twenty four) months calculated from the current tax payable pursuant to Rule Batam Mayor Number 23 Year 2012 on Amendments to the Law Mayor Batam number 23 Year 2011 concerning the Implementation Guidelines hotel tax, restaurant tax, amusement tax, street lighting tax, tax Non Metallic Minerals and rocks, Batam City parking tax.

Tax compliance by Devano and Rahayu (2006) is obedience, submissive and obedient and to implement tax provisions. Abiding taxpayer is the taxpayer who obey and fulfill and carry out tax obligations in accordance with the provisions of tax legislation.

According to Tia (2010) factors affecting tax compliance, among others: (1) state system of consciousness taxation of a State, (2) service to the taxpayer, (3) the enforcement of tax laws, (4) tax audit and (5) Rates tax. According Kurniawan (2006) factors that encourage tax compliance consist of a factor of knowledge or understanding of taxpayers regarding taxation.

Abiding taxpayer is the taxpayer that is obedient and submissive and have no overdue or delay the tax payment. This study aims to determine whether or not the influence of the relationship between the dependent variable levels of taxpayer compliance with the non-star hotels independent variables such as service, penalties for late payments and reporting. Sanjaya's research (2014) service quality and significant positive effect on the level of tax compliance.

This study intends to examine the relationship between service tax officials with tax compliance. Officers Services Tax (Fiscus) is very important effect on a tax payment and reporting activities so that taxpayers can easily ask questions if there are things that make them do not understand. Based on these descriptions' researchers propose the first hypothesis:

H1: Service tax officials' positive effect on the level of tax compliance of non-star hotel.

Research by Dewi dan Sukartha (2015) find empirical evidence that tax penalties positive effect on tax compliance in paying taxes hotel. In order not to be given tax penalties, the taxpayer must have the awareness to comply in paying taxes. With the 
awareness is there, then the taxpayer will avoid penalties for late payment. Based on these descriptions' researchers propose two hypotheses:

$\mathrm{H} 2$ : Penalties for late payment of local tax positive effect on the level of tax compliance.

Timeliness of reporting is compliance with the tax period that has been determined, namely 1 (one) month. In accordance with Regulation of City of Batam No. 5 of 2011 concerning Regional Tax Batam, the tax period is a period of 1 (one) calendar month or another time period which is regulated by the Mayor at the latest three (3) calendar months, which became the basis of the taxpayer to count, deposit and report taxes owed. If the taxpayer does not obey in report and pay the tax, it can be sanctioned.

In accordance with Regulation Batam Mayor Number 23 Year 2012 on the Amendment Regulation Batam Mayor Number 23 Year 2011 concerning the Implementation Guidelines Hotel Tax Non Metallic Minerals and Rocks, Parking Tax Batam reporting sanctions will be imposed if the taxpayer reported late tax no later than the date 15 (fifteen) per month with administrative sanctions such as fines of $2 \%$ (two percent), with penalties for late given to the taxpayer, the taxpayer would be obedient in tax reporting. Based on these descriptions, the authors propose a third hypothesis:

H3: Sanctions Delay in reporting positive effect on the level of tax compliance non-star hotels.

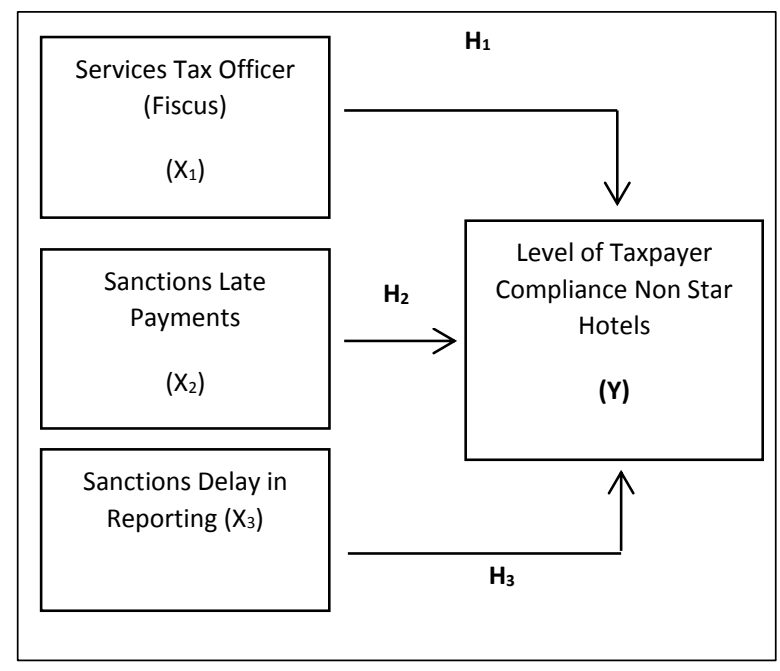

Fig. 1. Model Research

\section{Research Method}

In this study, researchers set the number of samples to be taken using slovin formula, as follows:

$$
\begin{aligned}
& n=\frac{N}{1+n e^{2}} \\
& n=\frac{133}{1+133(0.05)^{2}}=100 \\
& n \quad=\text { Respondent } \\
& N \quad=\text { Sample } \\
& e \quad=\text { error tolerance }
\end{aligned}
$$

Based on calculations using formulas slovin, the researchers determined the total sample of 100 samples (questionnaires) will be deployed. This study used a non-probability sampling technique (nonrandom), in the form of purposive sampling, because the information will be retrieved from sources that intentionally selected based on criteria established researchers (Sekaran, 2011). The criteria for the samples that taxpayers non-star hotels. The number of samples based on slovin calculation formula as many as 100 people, as many as 133 questionnaires were distributed and 116 were returned. The amount can be categorized based on their education and working period.

\section{Discussion}

Table 1 indicate that the data is the latest education respondents most is $\mathrm{S} 1$ with a percentage of $52.59 \%$ or as many as 61 people, the next on the ladder of DIII with a percentage of $25.86 \%$, or 30 people, high school/vocational school with a percentage of $18.96 \%$ or 22 people and last of education S2 with percentages $2: 59 \%$ or 3 people.

Table 1

Based on Education

\begin{tabular}{llrr}
\hline No. & Information & F & \multicolumn{2}{c}{ Percentage $(\%)$} \\
\hline 1 & <1 year & 6 & 5.17 \\
2 & 1-3 year & 91 & 78.45 \\
3 & >3 year & 19 & 16.38 \\
Total Respondents & 116 & 100 \\
\hline
\end{tabular}

Table 2 shows 5:17\% of respondents are less than 1 year, $78.45 \%$ worked $1-3$ years and who worked more than three years is the owner and manager of finance with 16:38\%. 
Table 2

Based on Working Period

\begin{tabular}{llrr}
\hline No. & Information & F & Percentage $(\%)$ \\
\hline 1 & SMA/SMK & 22 & 18.96 \\
2 & DIII & 30 & 25.86 \\
3 & S1 & 61 & 52.59 \\
4 & S2 & 3 & 2.59 \\
\multicolumn{2}{l}{ Total Respondents } & 116 & 100 \\
\hline
\end{tabular}

Tests conducted in this study is to test the validity and reliability testing. Based on testing that has been done shows that every item questionnaire on research variables are valid, as seen from the value of $r$ count every item that is larger than $r$ table of 0.3494 . Reliable test results in this study also shows that each variable has been reliable, visible from the variable service, penalties for late payments, penalties for late reporting and tax compliance each having Cronbach Alpha $(\alpha)$ of $0.843 ; 0.832 ; 0.623$ and 0.880 which the result is greater than the Standard Alpha Cronbach is 0.60.

Classic assumption test in this study using a test for normality, heteroscedasticity test and test multicollinearity. Test normality in this study using the statistical test skewness and kurtosis. Based on tests that have been done shows each skewness of $3.40 ; 1.27 ; 0.18$ and each kurtosis value of $1 ; 0.43$; 0.98 .

Table 3

Normality Test Results

\begin{tabular}{lrrrr}
\hline & $\mathrm{X}_{1}$ & $\mathrm{X}_{2}$ & $\mathrm{X}_{3}$ \\
\hline $\mathrm{N} \quad$ Valid $\quad$ Missing & 116 & 116 & 116 \\
& 0 & 0 & 0 \\
Skewness & -.773 & .290 & .042 \\
Std. Error of Skewness & .225 & .225 & .225 \\
Kurtosis & .454 & .197 & .085 \\
Std. Error of Kurtosis & .446 & .446 & .446 \\
\hline
\end{tabular}

This value is intended to find the $\mathrm{Z}$ value is calculated by using the formula:

$$
\begin{gathered}
\mathrm{X}_{1 \longrightarrow} \longrightarrow \quad \text { ZSkewness }=\frac{-0.773}{\sqrt{\frac{6}{116}}}=-3.40 \\
\text { ZKurtosis }=\frac{0.454}{\sqrt{\frac{24}{116}}}=1
\end{gathered}
$$

$$
\begin{gathered}
\mathrm{X}_{2} \longrightarrow \quad \text { ZSkewness }=\frac{0.290}{\sqrt{\frac{6}{116}}}=1.27 \\
\text { ZKurtosis }=\frac{0.197}{\sqrt{\frac{24}{116}}}=0.43 \\
\mathrm{X}_{3} \longrightarrow \quad \text { ZSkewness }=\frac{0.042}{\sqrt{\frac{6}{116}}}=0.18 \\
\text { ZKurtosis }=\frac{0.446}{\sqrt{\frac{24}{116}}}=0.98
\end{gathered}
$$

Based on the results of the normality test is known that each ZSkewness of $-3.40 ; 1.27 ; 0.18$ and ZKurtosis is $1 ; 0.43 ; 0.98$ with a significance level of 0.05 is smaller than the $\mathrm{Z}$ table is 1.96. Based on the statistical test results obtained it can be concluded that the data were normally distributed.

Heteroskedasticities test results in this study are as follows:

Tablel 4

Test Results Heteroskidastity

\begin{tabular}{llll}
\hline \multicolumn{2}{l}{ Model } & Sig. & $\alpha$ \\
\hline 1 & (Constant) & .015 & \\
& $\mathrm{X}_{1}$ & .125 & 0.05 \\
& $\mathrm{X}_{2}$ & .138 & 0.05 \\
& $\mathrm{X}_{3}$ & .057 & 0.05 \\
\hline
\end{tabular}

Table 4 shows the value and alpha 0:05 Significance. seen that the variables Services $\left(\mathrm{X}_{1}\right)$ significant value $0.125>\alpha(0: 05)$, variable Penalties Late Payments $\left(\mathrm{X}_{2}\right)$ the value of the significant $0138>0.05$ and a variable delay Reporting $\left(\mathrm{X}_{3}\right) 0057>0.05$, which means none of the independent variables are statistically significant influencing variables dependent. So we can conclude that the regression model does not contain any heteroscedasticity. 
Multicollinearity test is also performed in this study with the following results:

Table 5

Test Results Multicolinearity

\begin{tabular}{lll}
\hline \multirow{2}{*}{ Variable } & \multicolumn{2}{c}{ Collinearity Statistics } \\
& Tolerance & VIF \\
\hline Services Tax Officer & .976 & 1.025 \\
Sanctions Late Payments & .817 & 1.224 \\
$\begin{array}{l}\text { Sanctions Delay } \\
\text { Reporting in }\end{array}$ & .812 & 1.231 \\
\hline
\end{tabular}

Table 5 shows that the data does not occur multicollinearities. It can be seen from the tolerance of each independent variable is greater than 0.10 and VIF value of each variable is less than 10 .

\section{Hypothesis Test}

Hypothesis Test is also performed in this study with the following results:

Table 6 Hypothesis Test Results

\begin{tabular}{llllll}
\hline & & & & & \\
& & Std. Error $\beta$ & $\mathrm{T}$ & Sig. \\
\hline Constant & 20.323 & 4.639 & & 4.380 & .000 \\
$\mathrm{X}_{1}$ & .220 & .101 & .189 & 2.173 & .032 \\
$\mathrm{X}_{2}$ & .404 & .186 & .207 & 2.176 & .032 \\
$\mathrm{X}_{3}$ & .390 & .185 & .201 & 2.115 & .037 \\
$\mathrm{R}^{2}$ & .152 & & & & \\
$\mathrm{R}$ & .418 & & & & \\
\hline
\end{tabular}

Based on the analysis above estimation model can be analyzed as follows:

$Y=20.323+0.220 \mathrm{X}_{1}+0.404 \mathrm{X}_{2}+0.390 \mathrm{X}_{3}$

Value Taxpayer Compliance showed a value of 20.323, which means an increase of 0.220 if the service was up 1 unit (assumed variables Services), rose by 0.404 if sanctions Late Payments rose 1 (assumed variables Penalties Late Payment) and rise by 0.390 if sanctions Delay Reporting ride 1 unit (assumed variables Sanctions delay Reporting).

To determine whether the independent variables simultaneously significant effect on the dependent variable, then tested F. confidence level used is 0.05 . If the value of $F$ result is greater than the $F$ table then the hypothesis that all independent variables simultaneously significant effect on the dependent variable. Based on the results of the processing see table 5 with significant value, namely $0.00<0.05$. this shows that the independent variable (performance, penalties for late payments and reporting) jointly able to explain the effect on the dependent variable (the level of tax compliance).

$\mathrm{t}_{\text {tabel }}$ value is $\alpha=0.05$ with degrees of freedom (db) $\mathrm{n}-\mathrm{k}=116-3=113$ is 1,981 . Based on the analysis on statistical table it can be seen the influence of the independent variables are as follows:

a. Hypothesis testing is done by comparing the significant value of 0.05 . Services for the variable $\left(\mathrm{X}_{1}\right) 0.03$ significance value. Thus, it can be said that the significant value $0.03<0.05$. The coefficient value of $22 \%$ of the variable $X_{1}$ is positive, is 0.220 . This suggests that this study may Service Tax Officer $\left(\mathrm{X}_{1}\right)$ positive and significant impact on tax compliance. Accordingly, $\mathrm{H}_{1}$ accepted.

b. Hypothesis testing for Late Payment Penalties variable $\left(\mathrm{X}_{2}\right)$ the value of significance 0.32 . thus, it can be said significance value of $<0.05$. Coefficient value $40.4 \% \mathrm{X}_{2}$ is positive 0.404 . These results indicate that the Sanctions Late Payments $\left(\mathrm{X}_{2}\right)$ positive and significant impact. Accordingly, $\mathrm{X}_{2}$ received.

Hypothesis testing for Reporting Delay Sanctions variable $\left(\mathrm{X}_{3}\right) 0.39$ significance value. Thus, it can be said significance value less than 0.05 . The coefficient value of $39 \%$ of the variable $X_{3}$ is positive 0.390 . These results indicate that the Sanctions Delay in Reporting $\left(\mathrm{X}_{3}\right)$ positive and significant impact. Accordingly, $\mathrm{X}_{3}$ received.

\section{Conclusions}

Based on the analysis and discussion, it can be concluded that the positive effect on the level of service tax compliance, which means the better the services provided to taxpayers increasingly obedient taxpayers in pay and report tax. Likewise, with the penalty of late payment and reporting positive effect on the level of tax compliance, which means the published regulations regarding the reporting of sanctions and the payment will be more compliant taxpayers in paying taxes because they do not want to subject to administrative sanctions a financial penalty.

Based on the analysis there are limitations in drafting, the attitude of concern and seriousness of respondents in answering the statements. Tax penalties either sanction or penalty payment reporting has a great influence on the compliance of the taxpayers. It should be on sanctions, the relevant 
agencies in this case the Revenue Service Batam can hold a good socialization to taxpayers in order that taxpayers better understand the tax penalties and what causes a taxpayer is fined, to raise awareness of the taxpayer it is necessary the socialization of the conscious attitude of society paying taxes. Socialization can be through advertising on television, newspapers, and radio so that people have an awareness of the importance of paying taxes on time. Taxpayers also should be aware of the importance to pay taxes on time to help realize the country's development, because it's actually a tax on the people, by the people and for the people, the people themselves will also to be enjoyed.

Services provided to taxpayers was also very big influence on adherence because of the care workers who serve taxpayers with pleasure then the taxpayer will feel that they are appreciated. So, care workers should further improve its services, concierge services are also expected to act professionally and mentally ready to serve the taxpayer with the best.

This study only uses the variable service, penalties for late payments and reporting. The study also recommends further research can use other variables that may increase tax compliance of taxpayers such as variable knowledge about taxes, a moral obligation, the attitude of the taxpayer and still other variables that can be used as a study variable, so it can be compared with the results of the study authors. Researchers further also can increase the number of samples to be studied, so that analysis of data may be more accurate.

\section{References}

Devano dan Rahayu, 2006. Perpajakan: Konsep, Teori, dan Isu. Kencana. Jakarta.

Dewi, Putu Septiana, Sukartha I Made. (2015). Faktor-Faktor yang mempengaruhi Kepatuhan Wajib Pajak Dalam Membayar pajak Hotel. E-Jurnal Akuntansi Universitas Udayana.

Jatmiko, (2006). Pengaruh Sikap Wajib pajak terhadap Pelaksanaan Sanksi Denda, Pelayanan Fiskus dan Kesadaran Perpajakan terhadap Kepatuhan wajib Pajak. Tesis Tidak Dipublikasikan, Program S2 Magister Akuntansi Universitas Diponegoro.

Kurniawan, P., \& Pamungkas, B. (2006). Penagihan Pajak di Indonesia. Malang; Penerbit Bayumedia

Resmi, Siti. (2015). Perpajakan Teori dan Kasus. Buku 2, Jakarta; Salemba Empat.

Sanjaya, Putra I. Putu Adi. (2014). Pengaruh Kualitas Pelayanan, Kewajiban Moral dan Sanksi Perpajakan pada Kepatuhan Wajib Pajak Hotel dalam Membayar Pajak Hotel. E-Jurnal Akuntansi Universitas Udayana.

Saputra, Robert. (2015). Pengaruh Sanksi, Kesadaran Perpajakan, dan Kualitas Pelayanan Wajib Pajak Terhadap Kepatuhan Wajib Pajak Bumi dan Bangunan (Studi Empiris Pada Wajib Pajak Kabupaten Pasaman). Jurnal Fakultas Ekonomi Universitas Negeri Padang.

Sekaran, Uma (2011) Research Methods for Business Edisi I. Jakarta: Salemba Empat

Suciningsih, Kadek., Bagia. Wayan, Cipta Wayan. (2015). Pengaruh Sanksi Perpajakan dan Kesadaran Wajib Pajak Terhadap Kualitas Pelayanan serta Dampaknya Pada Kepatuhan Wajib Pajak Dalam Membayar Pajak Bumi dan Bangunan. Jurnal Jurusan Manajemen Vol 3, No 1. Universitas Udayana

Waluyo. (2011). Perpajakan Indonesia. Jakarta: Salemba Empat. 